\title{
Prophylactic effect of levamisole on rainbow trout (Oncorhynchus mykiss) against Yersinia ruckeri ${ }^{1}$
}

\author{
Unal Ispir ${ }^{2}$
}

\begin{abstract}
Ispir U. 2009. Prophylactic effect of levamisole on rainbow trout (Oncorhynchus mykiss) against Yersinia ruckeri. Pesquisa Veterinária Brasileira 29(9):700-702. Faculty of Agriculture, Department of Fisheries, Bingol University, 23119 Bingol, Turkey. E-mail: uispir@yahoo.com

Alteration in the relative percentage of survival (RPS) rate of rainbow trout (Oncorhynchus mykiss) exposed to 5, 10 and $25 \mu \mathrm{g} \mathrm{ml}^{-1}$ levamisole for $2 \mathrm{~h}$ against Yersinia ruckeri was investigated. The average weight of the 120 fish used in this study was $6.3 \mathrm{~g}$. Upon challenge with a virulent strain, the relative survival percentage of respectively $83.3 \%, 86.7 \%$ and $76.6 \%$ was recorded. The results suggest that the application of levamisole in fish farms could increase resistance to infection of fish and offer economic benefits.
\end{abstract}

INDEX TERMS: Levamisole, rainbow trout, Oncorhynchus mykiss, Yersinia ruckeri, immunity, protection.

\section{INTRODUCTION}

Antibiotics, drugs and chemicals have been used for treating fish disease caused by environmental stress and other factors for years. However, these are often effective for only a short time and may accumulate in the environment. In the past, the immunological approach to preventing fish disease has been by vaccination against specific pathogens, where vaccines were used for treating a particular disease (Siwicki et al. 1994).

Immunostimulants is important to health as provides the building block of defence mechanisms and protection against disease several promising adjuvants, natural and synthetic drugs and biological modifiers have been tested in fish in vivo and in vitro. The substance are effective in stimulating or modulating non-specific defence mechanism, and offer protection against viral and bacterial diseases fish (Kodama et al. 1993, Siwicki et al. 1994, Mulero et al. 1998, Cuesta et al. 2002a).

Levamisole is a levo-isomer of tetramisole [6]. Previous studies have suggested that levamisole treatment leads to an enhanced state of resistance to various kinds of infections (Jeney et al. 1994, Mulero et al. 1998, Findlay \&

\footnotetext{
${ }^{1}$ Received on August 18, 2008.

Accepted for publication on May 14, 2009.

${ }^{2}$ Faculty of Agriculture, Department of Fisheries, Bingol University, 23119 Bingol, Turkey. E-mail: uispir@yahoo.com
}

Mundlay 2000). Levamisole is a registered and accepted drug for the Europen Comminity and the United States Food and Drug Administration, its metabolism is not well known. Toxicity and tissue residues have been reported after its use in some animals but not for fish (Cuesta et al. 2002b). The purpose of this study was to determine the influence of bath the levamisole on prophylactic effect Yersinia ruckeri in the intensive culture of rainbow trout (Oncorhynchus mykiss).

\section{MATERIALS AND METHODS}

Healty Oncorhynchus mykiss avarege weighing 6.3g, were obtained from local fish farming, Elazig, Turkey. The fish were kept in $90 \mathrm{~L}$ tanks, with water recirculation. The water was maintained at $14 \pm 2^{\circ} \mathrm{C}, \mathrm{pH} 7.3 \pm 0.1$, and dissolved $\mathrm{O}_{2} 9.2 \pm 0.4 \mathrm{mg}$ $\mathrm{ml}^{-1}$. The fish were red twice daily, 7 days a week. The fish were divided into 4 groups, with 30 fish in each group. After a 2 week acclimation period, the experimental groups were bathed for 2 hours with 5, 10 and $25 \mu \mathrm{g} \mathrm{ml}^{-1}$ levamisole. Control fish were immersed in tap water on the same schedule. Afterwards, all fish were immersed with $9.8 \times 10^{6} \mathrm{cell} \mathrm{ml}^{-1}$ of live Yersinia ruckeri for 2 minutes. Resulting deaths in the challenged fish were monitored for 21 days. Dead fish were removed and subjected to bacteriological examination. For each treatment, three replicates and control groups were used. The relative percentage of survival (RPS) (Amend, 1981) was calculated to evaluate the efficacy of vaccination as:

RPS: [1 - (\%mortality in vaccinated fish / \% mortality in control) $] \times 100$ 
The mortality percentages and RPS obtained in the vaccination study was analysed using $t$-student test.

\section{RESULTS}

After challenge with cohabitants that were inoculated with Yersinia ruckeri, the relative percentage of survival (RPS) in all treatment groups was $83.3 \%, 86.7 \%$ and $74.66 \%$, respectively. However, fish that took bath without levamisole (control group) showed $100 \%$ mortality (Table 1, Fig.1). The survival levels in the levamisole-bathed groups were

Table 1. Mortality rates of rainbow trout after challenged

\begin{tabular}{ccccc}
\hline Groups & $\begin{array}{c}\text { Infected } \\
\text { fish }\end{array}$ & $\begin{array}{c}\text { Dead } \\
\text { fish }\end{array}$ & $\begin{array}{c}\text { Mortality } \\
\text { rates }(\%)\end{array}$ & $\begin{array}{c}\text { Protection } \\
\text { rates }(\%)\end{array}$ \\
\hline Experimental I & 30 & 5 & 16.66 & $83.3^{\mathrm{a}, \mathrm{d}}$ \\
Experimental II & 30 & 4 & 13.33 & $86.7^{\mathrm{a}, \mathrm{b}, \mathrm{d}}$ \\
Experimental III & 30 & 7 & 23.34 & $74.6^{\mathrm{a}}$ \\
Control & 30 & 30 & 100.00 & -
\end{tabular}

$\overline{{ }^{a} \text { Control, }{ }^{b} \text { Experiment I, }}{ }^{c}$ Experiment II, ${ }^{d}$ Experiment III, $\mathrm{p}<0.05$.

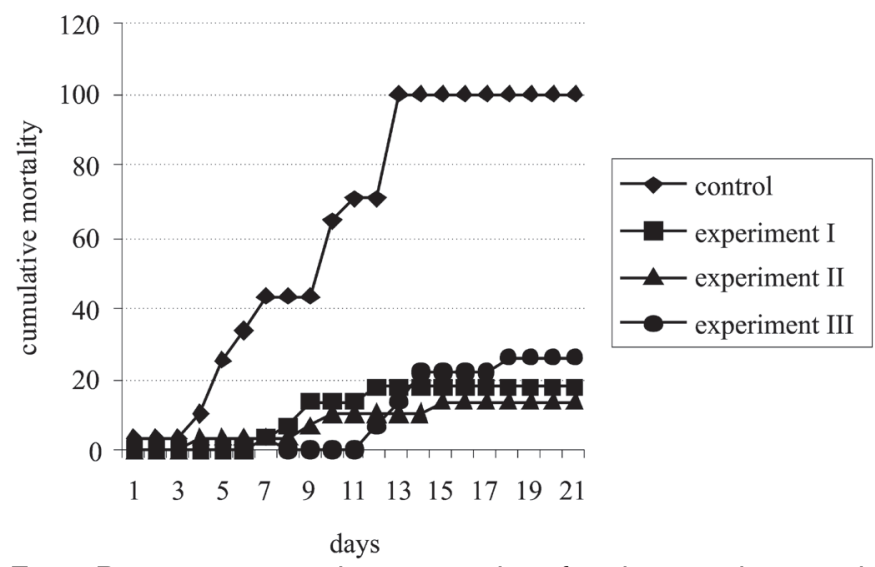

Fig.1. Percentage cumulative mortality after the inoculation with Yersionia ruckeri on control and experiment groups.

significantly different $(p<0.05)$. But, there were significant differences between all the experimentals groups and control group. Bacteriological analysis showed that dead fish (kidney inocula) infected with the inoculated bacteria.

\section{DISCUSSION}

A variety of immunomodulatory effects of levamisole has been establisment in higer vertebrates. Among the most widespread effect seems to be enhancement of non-specific and specific immunity. The patterns of assays for the nonspecific defence factors, the specific immune response and challenge tests all correlated with one another, strongly suggesting some relationship (Jeney \& Anderson 1993). The results presented in this paper show that Rainbow trout can be successfully vaccinated against infection of Yersinia ruckeri by bath of different doses of levamisole. A significantly lower mortality was achieved in all vaccinated groups than control, the fish were challenged with dose containing $9.8 \times 10^{6}$ cells $\mathrm{ml}^{-1}$ of $Y$. ruckeri.

After treatment with levamisole several fish species showed enhanced resistance to on experimental challenge with pathogenic bacteria. The use of levamisole with vaccines to increase the efficacy of the immune response against pathogenic microorganisms (Anderson \& Jeney 1992, Jeney \& Anderson 1993, Mulero et al. 1998, Sahoo \& Mukherjee 2002).

In this study all groups of fish given a bath treatment of levamisole had increased response against $Y$. ruckeri infection when compared to control fish. In those circumstances where the capacity to mouth an immune response may be adequate to ensure improved protection. Rainbow trout were experimentally infected with the virulent strain $Y$. ruckeri, and the protection rates of treatment I, II and III were $83.3 \%, 86.7 \%$ and $74.6 \%$, respectively, as suggested previously in other studies. Olivier et al. (1985), pointed out that Coho salmon (Oncorhynchus kisutch) and Chum salmon (Oncorhynchus keta) injected with levamisole mixed with Freund's complete adjuvant (FCA) showed increased resistance to Escherichia coli. Kajita et al. (1990), reported that rainbow trout injected with levamisole showed increased protection against Vibrio anguillarum, caused by the enhancement of non-specific immune responses such as phagocytic activity, chemiluminescance responses of leucocytes and NK cell activities. Baba et al. (1993), reported that carp immersed in a levamisole bath (10 mg/ml, $24 \mathrm{~h})$ showed enhanced resistance against $A e-$ romonas hydrophila. Mulero et al. (1998), also reported that gilthead seabream fed with levamisole enhanced resistance against Vibrio anguillarum. Baruah \& Prasad (2001), described that Macrobrachium rosenbergii were fed diets containing 0 (control), 125 and 250mg levamisole $\mathrm{kg}^{\prime 1}$ dry diet for 115 days, and then were experimentally infected with the virulent strain Pseudomonas fluorescent, and showed that the death of shrimp was delayed compared to that observed in control. Gopalakannan \& Arul (2006), reported that carp the treated with levamisole were challenged with $A$. hydrophila on the $45^{\text {th }}$ day, the relative percentage survival (RPS) was significantly higher in levamisole $(66.7 \%)$ fed fishes. However, the RPS decreased to $57.8 \%$ on the $90^{\text {th }}$ day after the challenge with $A$. hydrophila. Our results are in agreement with the results in previous investigations. Our results showed similarity to the results of previously investigated.

The findings in this study are in accordance with the previously discussed studies of the effects of levamisole in other fish species. The results of this study may prove to be practical value given the efficacy of this drug, invasion the pathogenic microorganisms. Thus, the prophylactic use of levamisole may be of value where situations known to result in stress and exposure to disease occur.

\section{REFERENCES}

Anderson D.P. \& Jeney G. 1992. Immunostimulants added to injected Aeromonas salmonicida bacterin enhances the defense mechanisms and protection in rainbow trout (Oncorhynchus mykiss). Vet. Immunol. Immunopathol. 34:379-389.

Baba T., Watase Y. \& Yoshinaga Y. 1993. Activation of mononuclear 
phagocyte function by levamisole immersion in carp. Amend D.F. 1981. Potency testing of fish vaccines. Dev. Biol. Standard 49:447-454. Nippon Suisan Gakkaishi 59:301-307.

Baruah N.D. \& Prasad K.P. 2001. Efficacy of levamisole as immunostimulant in Macrobrachium rosenbergii (de Man). J. Aquac. Trop. 16:149-158.

Cuesta A., Esteban M. \& Meseguer J. 2002a. Natural cytotoxic activity in seabream (Sparus aurata L.) and its modulation by Vitamin C. Fish Shellfish Immunol. 13:97-109.

Cuesta A., Esteban M. \& Meseguer J. 2002b. Levamisole is a potent enhancer of Gilthead Seabream natural cytotoxic activity. Vet. Immunol. Immunopathol. 89:169-174.

Findlay V.L. \& Munday B.L. 2000. Immunomodulatory effects of levamisole on the nonspecific immune system of Atlantic salmon, Salmo salar L. Aquaculture 23:369-378.

Gopalakannan A. \& Arul V. 2006. Immunomodulatory effects of dietary intake of chitin, chitosan and levamisole on the immune system of Cyprinus carpio and control of Aeromonas hydrophila infection in ponds. Aquaculture 255:179-187.

Jeney G. \& Anderson D.P. 1993. Enhanced immune response and protection in rainbow trout to Aeromonas salmonicida bacterin following prior immersion in immunostimulants. Fish Shellfish Immunol. 3:51-58.

Jeney G., Galeotti M. \& Volpatti D. 1994. Effects of immunostimulation on the non-specific immune response of sea bass, Dicentrarchus labrax, L. International Symposium on Aquatic Animal Health, Seattle, Washington, Sept. 4-8. (Abstract)

Kajita Y., Sakai M., Atsuta S. \& Kobayashi M. 1990. The immunomodulatory effects of levamisole on rainbow trout, Oncorhynchus mykiss. Fish Pathol. 25:93-98.

Kodama H., Hirota Y., Baba T. \& Azuma I. 1993. Activation of rainbow trout (Oncorhynchus mykiss) phagocytes by Muramyl dipeptide. Dev. Comp. Immunol. 17:127-140.

Mulero V., Estaban M.A., Munoz J. \& Meseguer J. 1998. Dietary intake of levamisole enhances the immune response and disease resistance of the marine teleost giltead seabream (Sparus aurata, L.). Fish Shellfish Immunol. 8:49-62.

Olivier G., Evelyn T.P.T. \& Lallier R. 1985. Immunity to Aeromonas salmonicida in coho salmon (Oncorhynchus kisutch) induced by modified Freund's complete adjuvant: its non-specific nature and the probable role of macrophages in the phenomenon. Dev. Comp. Immunol. 9:419432.

Sahoo P.K. \& Mukherjee S.C. 2002. The effect of dietary immunomodulation upon Edwarsiella tarda vaccination in healthy and immunocompromised Indian major carp, Labeo rohita. Fish Shellfish Immunol. 12:1-16.

Siwicki A.K., Anderson D.P. \& Rumsey G. 1994. Dietary intake of immunostimulants by rainbow trout affects non-specific immunity and protection against furunculosis. Vet. Immunol. Imunopathol. 41:125-139. 